\begin{tabular}{ll}
\hline \hline MINING AND METALLURGY INSTITUTE BOR & ISSN: 2334-8836 (Štampano izdanje) \\
UDK: 622 & ISSN: 2406-1395 (Online) \\
\hline \hline
\end{tabular}

Sanja Bajić, Radmila Gaćina*, Katarina Urošević, Suzana Lutovac*

\title{
ANALYSIS OF BLASTING IMPACTS AT THE OPEN PIT MANASTIRISTE NEAR TOPOLA ON THE MONASTERY COMPLEX
}

\begin{abstract}
This paper discusses the problems associated with the negative effects that accompany blasting operations, and the certain conclusions were derived. One of the negative effects of blasting operations is the phenomenon of seismic action and its effects on the buildings and the environment. Shock waves, induced by blasting, could cause damages to the building facilities and the environment. Those shocks seem to be very unfavorable to both humans and the environment. Therefore, certain standards were developed that define permissible values of impacts on buildings and people in buildings. In Serbia, there are no standards for assessing the impact of such shock waves. The international regulations and standards, mostly Russian and German, will be used to solve this problem.

This case study provides an overview the measurement of shock waves during blasting at the open pit Manastiriste near Topola in a function of the quantity of used explosives, their impact on the surrounding buildings with special reference to the Monastery of the Holy Archangel Michael, as well as the assessment of measurement results according to the appropriate scales in the world.
\end{abstract}

Keywords: blasting, shock waves, measurement, impact, seismics

\section{INTRODUCTION}

With the aim to reduce costs and increase production of blasted rock mass, as well as methods of exploitation the mineral resources, the large - hole blasting has been increasingly applied. Due to the need for increasing amounts of the rock mass, there is a need to increase the amounts of explosives, which means increasing the negative effects of blasting (seismic effects of blasting, effect of air waves, sound effect, blast induced fly rock, etc.) $[1,2]$.

During trial blasting, it is necessary to determine, among other things, the pattern of propagation of seismic waves in all directions, in which there is a risk of damage to buildings. This is achieved by monitoring the rate of oscillation of all three compo- nents, as well as the frequency and duration of the phenomenon. Measurements will be made using instruments which, as output data, provide the specified sizes. This particularly is applied to the buildings of the Monastery of the Holy Archangel Michael, located in the southeast direction at a distance of 250-300 $\mathrm{m}$ from the minefield.

In addition to properly selected explosives, determination, i.e. harmonization of appropriate geometry of blasting parameters is of great importance. The objective of determining the appropriate parameters is to increase utilization of the explosion energy to maximum, and to reduce the negative effects of blasting, primarily seismic effect [3].

\footnotetext{
* University of Belgrade, Faculty of Mining and Geology, Djusina 7, 11000 Belgrade, Serbia, e-mail: sanjabajic@sezampro.com; radmila.gacina@rgf.rs; katarina.urosevic@rgf.rs; suzana.lutovac@rgf.bg.ac.rs
} 


\section{GEOLOGICAL AND ENGINEERING CHARACTERISTICS OF DEPOSITS}

The marble deposit Manastiriste is located on the southern and southeastern slopes of the Mountain Vencac, on the eastern periphery of the village Brezovac. The basic rock mass is consisted of deposits of carbonate rocks: calcitic marbles of different varieties (white, gray, gray-white, pink in gray to purple shades and stripes). Roof and floor are consisted of the mica, dolomite, metamorphosed limestone, then quartzite, sericitic schist and delluvial cover. From the floor towards the roof alternate phyllite, quartzite and sericitic schists, then alternation of dolomite, limestone, marble and quartzite, dolomite, marble of different varieties (useful raw materials).

The quality of calcite marbles has the following indicators:

$\begin{array}{ll}\text { - mean content: } \mathrm{CaO} & 53.75 \% \\ \text { - mean content: } \mathrm{CaCO}_{3} & 96.05 \% \\ \text { - mean content: } \mathrm{MgO} & 1.17 \% \\ \text { - mean content: } \mathrm{MgCO}_{3} & 2.45 \% \\ \text { - total carbonate: } & 98.5 \%\end{array}$

- mean degree of whiteness: $\quad 90.266 \%$ - mean content of harmful components is low:

$\mathrm{SiO}_{2}-0.89 \% ; \quad \quad \mathrm{Al}_{2} \mathrm{O}_{3}-0.54 \%$;

$\mathrm{Fe}_{2} \mathrm{O}_{3}-0.098 \% ; \quad \mathrm{SO}_{3}-0.42 \%$;

$\mathrm{Na}_{2} \mathrm{O}-0,06 \% ; \quad \mathrm{K}_{2} \mathrm{O}-0,01 \%$;

$\mathrm{M}_{\mathrm{n}} \mathrm{O}_{2}-0.01 \%$; $\quad \mathrm{Pb}<0.2 \mathrm{ppm}$;

$\mathrm{Ni}<0.09 \mathrm{ppm} ; \quad \mathrm{Cd}-0.24 \mathrm{ppm}$;

$\mathrm{Cu} 7.88$ ppm; $\quad \mathrm{Cr}-6.88$;

$\mathrm{Hg}<0.008 \mathrm{ppm}$ and As $<0.05 \mathrm{ppm}$.

- raw material complies with the relevant Serbian standards regarding the use as calcium carbonate,

- can be used in metallurgy for all classes of quality; industrial paints and varnishes; sugar industry for quality class II; the mineral fertilizer industry; glass industry - for the IV and V quality classes; in fodder industry; in cement industry.

Laboratory geomechanical investigations - the tests of physical and mechanical properties were carried out on representative samples, whose results are given Table 2.1.

Table 2.1 Results of geomechanical investigations

\begin{tabular}{|l|c|}
\hline - Bulk density, $\gamma\left(\mathrm{t} / \mathrm{m}^{3}\right)$ & 2.71 \\
\hline - Angle of internal friction, $\left(\alpha^{\circ}\right)$ & $34^{\circ} 12^{\prime}$ \\
\hline - Cohesion, $\left(\right.$ daN $\left./ \mathrm{cm}^{2}\right)$ & 71.42 \\
\hline - Uniaxial compressive strength, $\left(\mathrm{daN} / \mathrm{cm}^{2}\right)$ & 651.73 \\
\hline - Tensile strength, $($ daN/cm & 2 \\
\hline - Velocity of longitudinal waves, $(\mathrm{m} / \mathrm{s})$ & 83.47 \\
\hline - Velocity of transverse waves, $(\mathrm{m} / \mathrm{s})$ & 4,452 \\
\hline - Dynamic modulus of elasticity, $\left(\mathrm{GN} / \mathrm{m}^{2}\right)$ & 2,107 \\
\hline - Dynamic Poisson's ratio & 32.15 \\
\hline
\end{tabular}

\section{CRITERIA FOR EVALUATION THE SEISMIC EFFECTS OF BLASTING}

The elastic deformations caused by the dynamic effect of explosive charges represent the oscillatory process, i.e. seismic effect of blasting. The resulting elastic deformation spread out in the form of elastic waves radially from the blast site. According to the form of transmission of elastic deformation, seismic waves can be divided into two basic groups: bulk and surface elastic waves. Among bulk elastic waves, the most famous are longitudinal and transverse waves, while among surface the elastic 
waves; the most famous are the Raylleigh and Love elastic waves. The action of explosion in the working environment creates all kinds of elastic waves at the same time, whereby the change of distance, changes their intensity [4].

The intensity of seismic waves can be determined by measuring one of the basic dynamic parameters of the actuated environment as follows: oscillation velocity (v), acceleration (a) or displacement of soil (x). Realization the connection between these parameters is possible by determination of one parameter instrumentally, which allows the other parameters to be be determined by calculation. One of the most common parameters used for evaluation the seismic intensity is the oscillation velocity of actuated soil (v).

Maximum resulting soil oscillation velocity $\left(V_{\max }\right)$ is obtained as the intensity of the vector components in directions of $\mathrm{X}, \mathrm{Y}$ and $\mathrm{Z}$-axis, using the formula:

$$
v_{\max }=\sqrt{V_{v}^{2}+V_{l}^{2}+V_{t}^{2}},(\mathrm{~mm} / \mathrm{s})
$$

Where:

$v_{v}$ - vertical component of soil oscillation velocity $(\mathrm{mm} / \mathrm{s})$,

$v_{l}$ - longitudinal component of soil oscillation velocity $(\mathrm{mm} / \mathrm{s})$,

$v_{t}$ - transverse component of soil oscillation velocity $(\mathrm{mm} / \mathrm{s})$.

\subsection{Scales for Assessment the Seismic Effects of Blasting}

In larger number of countries there are regulations governing the level of shocks caused by explosions with which buildings can be loaded, depending on their nature, status and dynamic resistance. These regulations have not been adopted in our country, therefore the international regulations and standards, mostly Russian, German and American, are used in solving of this issue. Some criteria are given in the following table.

- Seismic scale of the Institute of Physics of the Earth, Russian Academy of Sciences - used for assessment the blast induced shocks is shown in Table 3.1.

Table 3.1 Seismic scale of the Russian Academy of Sciences

\begin{tabular}{|c|c|l|}
\hline $\begin{array}{c}\text { Oscillation } \\
\text { Velocity v [mm/s] }\end{array}$ & $\begin{array}{c}\text { Level of } \\
\text { seismic intensity }\end{array}$ & \multicolumn{1}{|c|}{ DESCRIPTION OF ACTIONS } \\
\hline To 2.0 & I & Action is revealed only by instruments \\
\hline $2.0-4.0$ & II & $\begin{array}{l}\text { Action is felt only in some cases when there is a complete } \\
\text { silence }\end{array}$ \\
\hline $4.0-8.0$ & III & $\begin{array}{l}\text { Action is felt by very few people or only those who are } \\
\text { expecting it }\end{array}$ \\
\hline $8.0-15.0$ & IV & $\begin{array}{l}\text { Action is felt by many people, the clink of the window- } \\
\text { pane is heard }\end{array}$ \\
\hline $15.0-30.0$ & V & Plaster fall, damage on buildings in poor condition \\
\hline $15.0-30.0$ & V & Plaster fall, damage on buildings in poor condition \\
\hline $30.0-60.0$ & VI & $\begin{array}{l}\text { Air cracks in plaster, damage, damage to buildings that } \\
\text { already have developed deformations }\end{array}$ \\
\hline $60.0-120.0$ & VII & $\begin{array}{l}\text { Damage to buildings in good condition, cracks in plaster, } \\
\text { parts of the plaster fall down, air cracks in walls, cracks in } \\
\text { tile stoves, chimney wrecking }\end{array}$ \\
\hline $120.0-40.0$ & VIII & $\begin{array}{l}\text { Considerable deformations on buildings, cracks in bear- } \\
\text { ing structure and walls, bigger cracks in partition walls, } \\
\text { wrecking of factory chimneys, fall of the ceiling }\end{array}$ \\
\hline $240.0-480.0$ & IX & $\begin{array}{l}\text { Wrecking of buildings, bigger cracks in walls, exfoliation } \\
\text { of walls, collapse of some parts of the walls }\end{array}$ \\
\hline Bigger than 480.0 & X - XII & $\begin{array}{l}\text { Bigger destruction, collapse of complete structures, } \\
\text { etc. }\end{array}$ \\
\hline
\end{tabular}


Permissible oscillation velocities in building structures (residential, industrial, etc.) dependon the type of structure, character and purpose. For these reasons, all buildings are divided into four classes.

Class I - especially important facilities of federal and republic importance, architectural and historical monuments. Blasting in the vicinity of these objects is possible only in the exceptional cases.

Class II - industrial buildings of great importance: pipelines, large factory halls, export towers in mines, water towers and similar facilities whose lifetime is longer than 20 - 30 years; residential buildings with greater number of inhabitants, cultural centers, cinemas and other.

Class III - industrial buildings and administrative buildings of relatively small size, whose height does not exceed three stories: mechanical workshops, compressor stations and similar facilities; residential buildings inhabited by fewer people, warehouses and similar.

Class IV - buildings and industrial facilities where expensive machinery and equipment are placed and whose damage does not endanger human life and health; warehouses, automobile bases, cold storage buildings, compressor stations and similar.

- Criteria in the FR of Germany This standard contains information on determination and evaluation the vibrations on building structures. Standard states the approximate values whose compliance cannot cause damages in terms of reducing the use value of building structure.

Assessment of total vibrations on structures is carried out from a numerous measurements of oscillation velocity on the foundation and ceiling structures. For this assessment the maximum value is taken for three individual components of oscillation velocity (see Table 3.2).

Table 3.2 Approximate values for oscillation (v) and oscillation frequency

\begin{tabular}{|c|c|c|c|c|c|}
\hline \multirow{4}{*}{ Row } & \multirow{4}{*}{ Type of the structure } & \multicolumn{4}{|c|}{$\begin{array}{c}\text { Approximate values of } \\
\text { vibration velocity }(\mathrm{v}) \mathrm{mm} / \mathrm{s}\end{array}$} \\
\hline & & \multicolumn{3}{|c|}{ Foundation } & $\begin{array}{l}\text { Top floor } \\
\text { ceilings }\end{array}$ \\
\hline & & \multicolumn{3}{|c|}{ Frequency, HZ } & \multirow{2}{*}{$\begin{array}{c}\text { All } \\
\text { frequencies }\end{array}$} \\
\hline & & $<10$ & $10-50$ & $50-100$ & \\
\hline 1 & $\begin{array}{l}\text { Structures used for craftsmanship, indus- } \\
\text { trial and similar structural structures }\end{array}$ & 20 & $20-40$ & $40-50$ & 40 \\
\hline 2 & $\begin{array}{l}\text { Dwelling buildings and structures similar } \\
\text { in construction or function. }\end{array}$ & 5 & $5-15$ & $15-20$ & 15 \\
\hline 3 & $\begin{array}{l}\text { Structures that because of their particular } \\
\text { sensitivity to vibrations do not fall into } \\
\text { groups } 1 \text { and } 2 \text { and are essential for con- } \\
\text { servation (for inst. as cultural-historical } \\
\text { monuments) }\end{array}$ & 3 & $3-8$ & $8-10$ & 8 \\
\hline
\end{tabular}

\section{MEASUREMENT AND BLASTING PARAMETERS}

Measurement of seismic effects, i.e. soil particles oscillation velocity (v) actuated by blasting was carried out using the measuring instrument type
Vibraloc, a product of the Swedish company ABEM. The basic characteristics of seismographs Vibraloc are as follows: 
* Measurement possibilities

* Frequency range

* Location possibilities

* Trigger levels

* Sampling

* Recording length

* Data transfer

* Data analysis
Velocity, acceleration, displacement and air impacts $2-250 \mathrm{~Hz}$

Flat floors, slabs, foundations, soil and other $0.1-200 \mathrm{~mm} / \mathrm{s}$ 1000,2000 or $4000 \mathrm{~Hz}$ $1-100 \mathrm{~s}$ or automatic length Vibraloc PC software UVSZ software; UVSZA software

Measuring points were located in the following places:

- Measuring point MP-1

- Measuring point MP-2

- auxiliary facility for water

- Measuring point MP-3

- at $20 \mathrm{~m}$ from MP-1

- Measuring point MP-4

- at $2 \mathrm{~m}$ from the bell, to the right

- in the middle of dormitory, $1 \mathrm{~m}$ from the slope

Blasting parameters and funds spent pit Manastiriste are shown in Table 4.1. for trial blasting operations at the open

Table 4.1 Blasting parameters and funds spent

\begin{tabular}{|l|c|c|c|c|c|c|c|c|c|c|c|}
\hline \multirow{2}{*}{$\begin{array}{c}\text { Funds spent per } \\
\text { blasting }\end{array}$} & \multicolumn{10}{|c|}{ Number of trial blasting } \\
\cline { 2 - 13 } & $\mathbf{1}$ & $\mathbf{2}$ & $\mathbf{3}$ & $\mathbf{4}$ & $\mathbf{5}$ & $\mathbf{6}$ & $\mathbf{7}$ & $\mathbf{8}$ & $\mathbf{9}$ & $\mathbf{1 0}$ & $\mathbf{1 1}$ \\
\hline $\begin{array}{l}\text { Total number of } \\
\text { boreholes, } \mathrm{N}_{\mathrm{b}}\end{array}$ & 1 & 2 & 4 & 4 & 3 & 5 & 4 & 5 & 8 & 4 & 5 \\
\hline $\begin{array}{l}\text { Total length of } \\
\text { boreholes } \mathrm{L}_{\mathrm{uk}}, \mathrm{m}\end{array}$ & 20.5 & 43.8 & 42.1 & 29.0 & 32.5 & 39.0 & 50.0 & 80.0 & 35.5 & 38.5 \\
\hline $\begin{array}{l}\text { Total quantity of } \\
\text { explosive } \mathrm{Quk}_{\mathrm{uk}}, \mathrm{kg}\end{array}$ & 53.3 & 117.6 & 256.7 & 254.7 & 157.9 & 133.0 & 140.0 & 193.5 & 229.5 & 152.0 & 91.0 \\
\hline $\begin{array}{l}\text { Max. quantity per } \\
\text { interval } \mathrm{Q}_{\mathrm{i}}, \mathrm{kg}\end{array}$ & 53.3 & 60.8 & 66.3 & 70.3 & 64.3 & 35.3 & 38.0 & 41.5 & 48.0 & 44.0 & 21.5 \\
\hline $\begin{array}{l}\text { Nonel detonator, } \\
25 / 500 \mathrm{~N}_{\mathrm{d}}, \mathrm{pcs} .\end{array}$ & 1 & 2 & 4 & 4 & 3 & 5 & 4 & 5 & 8 & 5 & 5 \\
\hline $\begin{array}{l}\text { Delay time } \\
\text { between } \\
\text { boreholes ms }\end{array}$ & - & 50 & 50 & - & - & - & - & - & - & - & - \\
\hline $\begin{array}{l}\text { Stemming length } \\
\mathrm{L}_{\check{c}}, \mathrm{~m}\end{array}$ & 3.5 & 3.5 & $3.5-4.0$ & $3.5-4.0$ & 3.5 & $2.0-5.0$ & 3.5 & 3.5 & $3.0-3.5$ & $3.0-3.5$ & $3.0-3.5$ \\
\hline $\begin{array}{l}\text { El. detonator } \mathrm{N}_{\mathrm{ed}}, \\
\text { pc. }\end{array}$ & 1 & 1 & 1 & 1 & 1 & 1 & 1 & 1 & 1 & 1 & 1 \\
\hline
\end{tabular}

Centre of explosion of minefields are shown in Figures 1 and 2. (MP) and locations of measuring points 


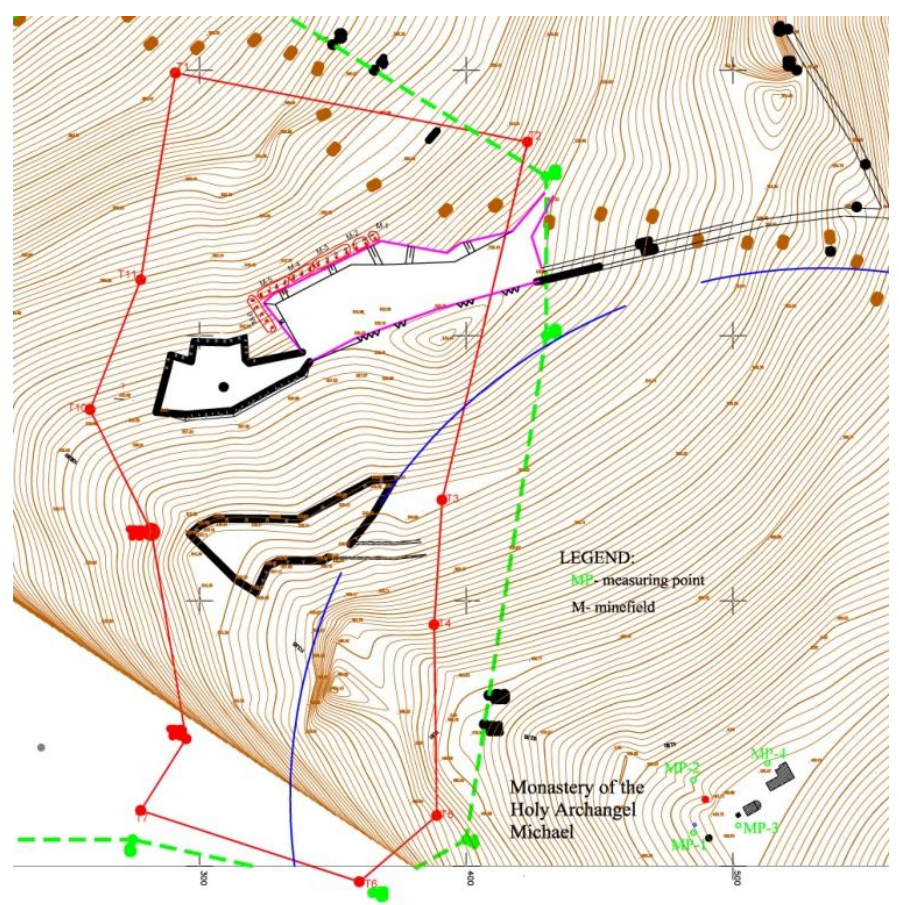

Figure 1 Locations of minefields M-1 to M-6 in relation to the measuring points

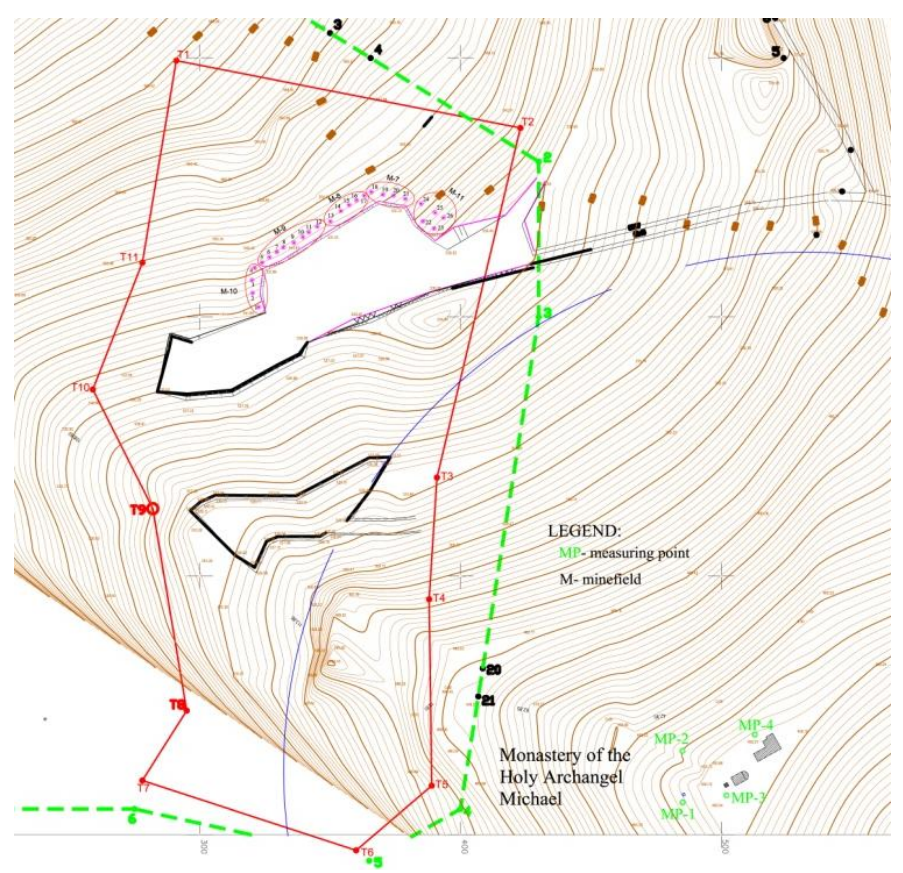

Figure 2 Locations of minefields M-7 to M-11 in relation to the measuring points 
Schematic view of boreholes arrandiagram including the order of initiation of gement, structure of charge and connection boreholes is shown in Figure 3

a)

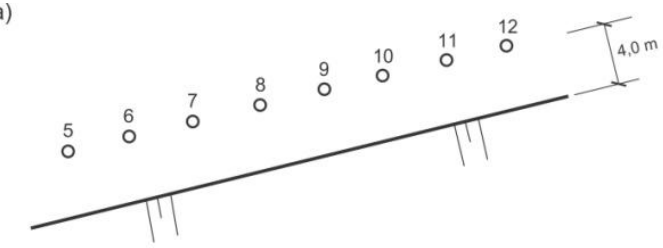

LEGEND:

MB - mine borehole

IP- impact patron

A-1 - explosive Amonex-1

A- explosive ANFO

ND - nonel detonator, $25 / 500$

NT - nonel tube

b) er, $25 \mathrm{~ms}$

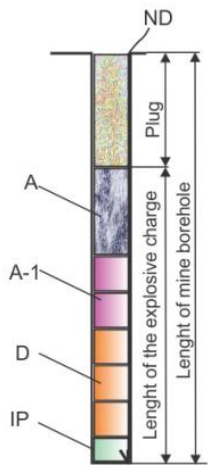

$\mathrm{ED}$ - el.detonator

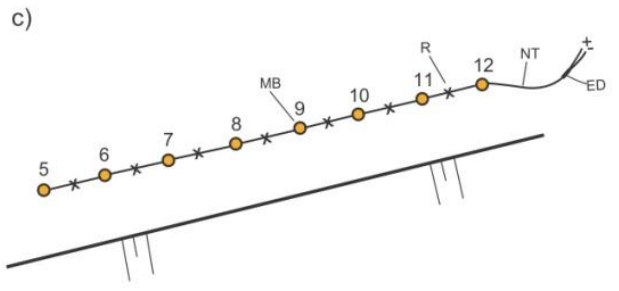

Figure 3 Borehole arrangement, structure of charge and connection diagram with performed blasting No. IX

\section{REVIEW THE MEASUREMENT RESULTS}

In order to evaluate the shocks in Table 5.1, the following is given: registered velocity values per components, resulting maximum oscillation velocity, frequency per components, whose value shall be compared with the values given in Tables 3.1 and 3.2.

For fulfilling the Table 5.1, the following marks are used for the assessment of performed blastings as follows:

- Criterion according to the scale of the Institute of Physics of the Earth, Russian Academy of Sciences (I Class facilities are taken):

- A - satisfies, within the limits of permitted oscillation velocity,
- B - does not satisfy, above the values of permitted oscillation velocity.

- Criterion according to DIN 4150 (III Class facilities are taken in accordance with Table 3.2):

- C - satisfies, within the limits of permitted oscillation velocity,

- D - does not satisfy, above the values of permitted oscillation velocity.

Figure 4 shows a graphic representation of velocigram of the blast No. X, at the measuring point MP-1 performed at the open pit Manastiriste - near Topola. 


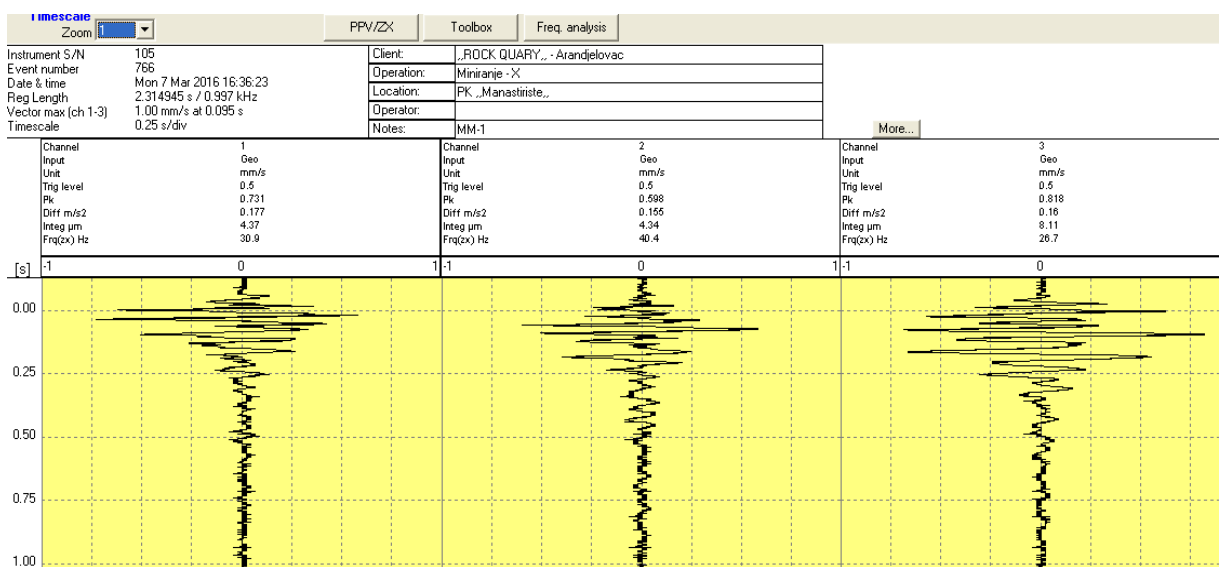

Figure 4 Snapshot of soil oscillation velocity for blast No. X at the measuring point MP-1

Table 5.1 Measurement results of trial blasts performed at the open pit Manastiriste near Topola

\begin{tabular}{|c|c|c|c|c|c|c|c|c|c|c|c|c|c|}
\hline \multirow{2}{*}{$\begin{array}{l}\text { Blasting } \\
\text { No. }\end{array}$} & \multirow{2}{*}{$\begin{array}{l}\text { Measuring } \\
\text { point M.P. }\end{array}$} & \multirow{2}{*}{$\begin{array}{l}\text { Dist. from blasting } \\
\text { field to measuring } \\
\text { point, } m\end{array}$} & \multirow{2}{*}{$\begin{array}{c}\text { Max, quantity } \\
\text { per one inter. } \mathrm{kg} \text {. }\end{array}$} & \multirow{2}{*}{$\begin{array}{c}\text { Overall } \\
\text { quantity of } \\
\text { exp. in } k g\end{array}$} & \multicolumn{3}{|c|}{$\begin{array}{l}\text { Maximum oscillation } \\
\text { velocity per comp. mm/s }\end{array}$} & \multirow{2}{*}{$\begin{array}{l}\text { Res, max. } \\
\text { oscillation } \\
\text { velocity } \\
m m m s\end{array}$} & \multicolumn{3}{|c|}{$\begin{array}{l}\text { Frequency per components, } \\
\qquad \mathrm{Hz}\end{array}$} & \multicolumn{2}{|c|}{$\begin{array}{c}\text { Evaluation of } \\
\text { measurement results }\end{array}$} \\
\hline & & & & & $V_{r}$ & $V_{7}$ & $V_{L}$ & & $V$ & $T$ & $L$ & By IFZA & By DIN \\
\hline \multirow[t]{4}{*}{1} & MP-I & 253.95 & 53.0 & 53.0 & $\cdot$ & $\cdot$ & $\cdot$ & &. &. & . & $A$ & C \\
\hline & MP-2 & 236.55 & 53.0 & 53.0 & 0.358 & 0.420 & 0.594 & 0.811 & 40.7 & 35.6 & 35.6 & A & C \\
\hline & MP. 3 & 259.78 & 53.0 & 53.0 & $\cdot$ & $\cdot$ &. &. &. & $\cdot$ & $\cdot$ & A & C \\
\hline & MP-4 & 246.39 & 53.0 & 53.0 & $\cdot$ & $\cdot$ & . & . &. &. &. & $A$ & C \\
\hline \multirow[t]{4}{*}{ II } & MP-1 & 254.35 & 117.0 & 60.5 & 0.364 & 0.754 & 0.562 & 1.008 & 24.9 & 22.63 & 33.2 & A & C \\
\hline & MP-2 & 237.03 & 117.0 & 60.5 & 0.626 & 0.774 & 0.924 & 1.358 & 38.9 & 29.3 & 20.9 & A & C \\
\hline & MP.3 & 260.45 & 117.0 & 60.5 & 0.475 & 0.508 & 0.516 & 0.860 & 30.5 & 19.9 & 27.7 & A & C \\
\hline & MP-4 & 247.52 & 117.0 & 60.5 & 0.465 & 0.450 & 0.597 & 0.880 & 17.7 & 17.2 & 25.6 & A & C \\
\hline \multirow[t]{4}{*}{ III } & MP-I & 255.34 & 255.5 & 66.0 & 0.545 & 0.931 & 0.652 & 1.260 & 23.7 & 24.3 & 22.1 & A & C \\
\hline & MP-2 & 238.77 & 255.5 & 66.0 & 0.649 & 0.796 & 1.541 & 1.852 & 26.2 & 33.8 & 24.2 & A & C \\
\hline & MP-3 & 262.74 & 255.5 & 66.0 & 0.656 & 0.596 & 0.605 & 1.073 & 24.8 & 17.2 & 26.2 & A & C \\
\hline & MP-4 & 250.55 & 255.5 & 66.0 & 0.598 & 0.517 & 0.597 & 0.991 & 21.1 & 33.2 & 23.2 & A & C \\
\hline \multirow[t]{4}{*}{ IV } & MP-1 & 256.62 & 253.5 & 70.3 & 0.866 & 0.776 & 0.495 & 1.277 & 19.8 & 21.1 & 26.8 & A & C \\
\hline & MP-2 & 240.74 & 253.5 & 70.3 & 0.626 & 0.796 & 1.168 & 1.546 & 23.4 & 17.8 & 22.4 & $\mathrm{~A}$ & C \\
\hline & MP.3 & 264.72 & 253.5 & 70.3 & 0.678 & 0.331 & 0.538 & 0.926 & 24.4 & 34.4 & 24.9 & A & C \\
\hline & MP-4 & 253.59 & 253.5 & 70.3 & 0.465 & 0.450 & 0.685 & 0.942 & 20.2 & 26.2 & 36.5 & A & C \\
\hline \multirow[t]{4}{*}{ V } & MP-1 & 258.49 & 157.0 & 64.0 & 0.636 & 0.599 & 0.585 & 1.051 & 19.7 & 11.9 & 19.5 & A & C \\
\hline & MP-2 & 243.28 & 157.0 & 64.0 & 0.492 & 1.040 & 0.748 & 1.372 & 32.2 & 18.0 & 39.1 & A & C \\
\hline & MP-3 & 266.93 & 157.0 & 64.0 & 0.520 & 0.486 & 0.807 & 1.122 & 26.6 & 21.1 & 18.9 & A & C \\
\hline & MP-4 & 257.26 & 157.0 & 64.0 & 0.433 & 0.405 & 0.552 & 0.815 & 19.9 & 20.5 & 20.8 & A & C \\
\hline \multirow[t]{4}{*}{ VI } & MP-1 & 253.85 & 132.0 & 35.0 & 1.159 & 0.931 & 0.787 & 1.682 & 22.9 & 15.6 & 22.9 & $A$ & C \\
\hline & MP-2 & 238.78 & 132.0 & 35.0 & 0.984 & 1.261 & 1.409 & 2.087 & 23.7 & 21.6 & 34.4 & A & C \\
\hline & MP-3 & 262.97 & 132.0 & 35.0 & 0.814 & 0.817 & 0.807 & 1.407 & 21.2 & 27.4 & 18.7 & A & C \\
\hline & MP-4 & 253.89 & 132.0 & 35.0 & 0.797 & 0.697 & 0.795 & 1.324 & 18.2 & 17.4 & 19.2 & A & C \\
\hline \multirow[t]{4}{*}{ VII } & MP-I & 260.31 & 140,0 & 38.0 & 0.421 & 0.775 & 0.730 & 1.145 & 22.7 & 17.4 & 16.3 & A & C \\
\hline & MP-2 & 242.44 & 140.0 & 38.0 & $\cdot$ &. &. & $\cdot$ &. &. & $\cdot$ & A & C \\
\hline & MP-3 & 265.94 & 140.0 & 38.0 & . &. & . &. &. & $\cdot$ &. & A & C \\
\hline & MP.4 & 251.11 & 140.0 & 38.0 & $\cdot$ & $\cdot$ & $\cdot$ &. &. &. &. & $A$ & C \\
\hline \multirow[t]{4}{*}{ VIII } & MP-I & 262.89 & 193.5 & 41.5 & 0.354 & 0.620 & 0796 & 1.069 & 23.7 & 23.0 & 22.7 & $A$ & C \\
\hline & MP-2 & 245.44 & 193.5 & 41.5 &. &. &. & . &. &. & $\cdot$ & A & C \\
\hline & MP-3 & 268.96 & 193.5 & 41.5 & $\cdot$ &. &. &. & . & $\cdot$ &. & A & C \\
\hline & MP-4 & 255.94 & 193.5 & 41.5 &. & . &. & $\cdot$ & . & . & . & A & C \\
\hline \multirow[t]{4}{*}{ IX } & MP-I & 262.91 & 229.5 & 47.5 & 0.709 & 1.085 & 0.951 & 1.607 & 26.8 & 19.2 & 15.2 & A & C \\
\hline & MP-2 & 247.15 & 229.5 & 47.5 & 0.643 & 0.771 & 0.675 & 0.924 & 30.5 & 16.3 & 23.5 & A & $\mathrm{c}$ \\
\hline & MP-3 & 270.84 & 229.5 & 47.5 & $\cdot$ &. &. & . &. &. &. & A & C \\
\hline & MP-4 & 259.87 & 229.5 & 47.5 &. &. &. & . & . & . &. & A & C \\
\hline \multirow[t]{4}{*}{$x$} & MP-I & 258.19 & 152.0 & 44.0 & 0.731 & 0.598 & 0.818 & 1.249 & 30.9 & 40.4 & 26.7 & A & C \\
\hline & MP-2 & 242.72 & 152.0 & 44.0 & 0.444 & 0.683 & 0.436 & 0.924 & 30.7 & 23.7 & 24.0 & A & C \\
\hline & MP-3 & 266.76 & 152.0 & 44.0 &. & . & . & . & . & . & . & $A$ & C \\
\hline & MP-4 & 257.96 & 152.0 & 44.0 & $\cdot$ & $\cdot$ &. & . & . & . & . & $\mathrm{A}$ & C \\
\hline $\mathrm{XI}$ & MP-1 & 246.67 & 91.0 & 21.5 & 0.487 & 0.421 & 0.597 & 0.878 & 23.7 & 18.8 & 185 & $\mathrm{~A}$ & C \\
\hline & MP-2 & 228.42 & 91.0 & 21.5 &. & $\cdot$ & $\cdot$ & . &. &. &. & $A$ & C \\
\hline & MP.3 & 251.56 & 91.0 & 21.5 & . &. & . &. &. & . & . & A & C \\
\hline & MP-4 & 236.28 & 91.0 & 21.5 & . & . & . &. & . &. &. & A & C \\
\hline
\end{tabular}




\section{CONCLUSION}

This case study shows the results of measurements the seismic impacts caused by trial blasting at the open pit Manastiriste near Topola.

The assessment of shocks on surrounding facilities during blasting operations was carried out based on criteria according to the scale of the Institute of Physics of the Earth, Russian Academy of Sciences and DIN.

Measuring points in the vicinity of the open pit Manastiriste were located in the vicinity of the Monastery of the Holy Archangel Michael, as shown in Figures 1 and 2.

Blasting operations at the open pit Manastiriste location near Topola were carried out under the following conditions:

- 11 trial blastings were performed,

- trial blastings were carried out for the purpose of creating the conditions for marble exploitation applying blasting operations,

- explosives Detonex 60/1500 and 70/2000; Amonex-1 60/1000, 70/1500 and ANFO-J in sacks $25.0 \mathrm{~kg}$ were used for blasting operations,

- quantity of explosives used during blastings varied from $53.0-255.5 \mathrm{~kg}$,

- maximum quantity of explosive per one interval was $70.3 \mathrm{~kg}$,

- initiation of explosives was performed with NONEL detonator 25/500.

On the basis of the results obtained for blasting operations and measurements, carried out at the open pit Manastiriste, the following conslusions can be derived:

1. The total of 11 trial blasting operations was performed and 24 results of oscillation velocity were instrumentally recorded at 4 measuring points.
2. The recorded values of oscillation velocity in the complex of the Monastery of the Holy Archangel Michael (measuring points MP-1; MP-2; MP-3; MP-4), are in the domain of permissible values in view of their impact on building structures, therefore it can be concluded that they do not have an impact on building structures.

3. During blasting operations and measurements at the open pit Manastiriste, there were no fly rocks induced by blasting, cancellation of blasting and similar, therefore the blasting went well.

4. With the aim of a more detailed consideration of blasting impacts, as well as the importance of the monastery itself, it is necessary to conduct the visit and view of all monastery buildings before each blasting in order to ascertain the status of buildings before blasting operations.

5. If there is a change in blasting technology, it is necessary to make a new recording of seismic impacts.

\section{REFERENCES}

[1] Lutovac S., Trajković S., Bajić S., Gaćina R.: Study of Seismic Impact of Blasting at the Open Pit "Manastirište", near Topola to the Surrounding Structures with Special Reference to the Monastery of St. Archangel Michael, Faculty of Mining and Geology, Belgrade, 2016, pp. 1-35 (in Serbian)

[2] Ravilić M.: Analysis of Blasting Impact on the Environment and Building Structures, Faculty of Mining and Geology, Belgrade, 2012 (in Serbian) 
[3] Trajković S., Lutovac S.: Protection Against Blasting, Faculty of Mining and Geology, Belgrade, 2014 (in Serbian)
[4] Rakić A.: Seismics of Blasting, ssociation of Engineers and Technicians, NIS - Naftagas, Novi Sad, 2005 (in Serbian) 